\title{
Efeitos da titulação de doses no perfil de tolerabilidade de Tramadol de liberação prolongada* em pacientes com dor crônica não-oncológica
}

\author{
Effects of dose titration on the tolerability profile of sutained-release \\ Tramadol in patients with non-oncologic chronic pain
}

Antônio Carlos Camargo Amaral Filho ${ }^{1}$, Luiz Roberto Stigler Marczyk ${ }^{2}$

\section{RESUMO}

Este estudo multicêntrico teve por objetivo comparar os efeitos de dois esquemas posológicos no perfil de tolerabilidade do tramadol de liberação prolongada em pacientes com dor crônica não-oncológica. A casuística envolveu 189 pacientes com idade entre 14 e 75 anos, divididos em 2 grupos aleatoriamente: grupo A com 96 e o grupo B com 93 pacientes que receberam a medicação do estudo por 15 dias. O grupo A utilizou uma dose inicial de tramadol de liberação prolongada de $50 \mathrm{mg}$ a cada 12 horas por 3 a 7 dias, passando para uma dose de manutenção de $100 \mathrm{mg}$ a cada 12 horas até o $15^{\circ}$ dia. O grupo $B$ fez uso de uma dose padronizada de $100 \mathrm{mg}$ a cada 12 horas de tramadol de liberação prolongada durante os 15 dias do estudo.

Os aspectos analisados foram o tipo de dor crônica nãooncológica, a intensidade da dor através da escala visual analógica, a aderência ao tratamento prescrito, a necessidade do uso da medicação de resgate, os efeitos adversos, a avaliação global da eficácia pelo médico e pelo paciente, bem como a tolerabilidade global na opinião do médico e do paciente.

A dor de origem músculo-esquelética, definida como dor muscular com suas inserções no osso, foi a mais freqüente com $45,8 \%$ dos casos no grupo A, enquanto a dor osteoarticular foi a mais observada no grupo B (47,3\%). Verificou-se uma melhora altamente significante tanto intra grupos como entre grupos, quanto à intensidade da dor, com redução de $67 \%$ em ambos os grupos. No grupo A, $77,1 \%$ dos pacientes cumpriram adequadamente o tratamento prescrito e no grupo $B$, a proporção foi de $75,3 \%$, não havendo diferença estatisticamente significativa entre os grupos. Os grupos foram semelhantes entre si quanto à utilização da medicação de resgate, onde apenas $9,7 \%$ dos pacientes do grupo A e 15,1\% do grupo B necessitaram-na durante o período do estudo. Não houve diferença significante na freqüência de eventos adversos nos dois grupos ( $30,2 \%$ e $36,6 \%$ respectivamente).

\section{SUMMARY}

The main objective of this multicentric study was to compare the effects of two posologic schemes on the safety profile of slowrelease tramadol in patients with non-oncological chronic pain. One hundred, eighty nine patients aged between 14 and 75 years were enrolled and divided in two groups at random : group $A$, with 96 and group $B$ with 93 patients which received the study medication for 15 days. Group A received an initial dose of slow release tramadol of 50mg twice a day for 3 to 7 days, and then using $100 \mathrm{mg}$ twice a day until day 15. Group B received a standard dose of slow release tramadol 100mg bid during the study period.

The parameters analised were: type of non-oncological chronic pain, intensity of pain assessed by means of a Visual Analogue Scale, the compliance to the prescribed treatment, requirement of rescue medication, adverse events, global assessment of efficacy by the investigators and patients as well as global assessment of tolerability by the investigators and patients.

Musculoeskeletal pain, defined as muscular pain and its bone insertions, was the most frequent type in group $A(45.8 \%)$ while osteoarticular pain was the most observed in group B (47.3\%). A significant relief of the intensity of pain was shown within both groups and when compared with each other (67\% decrease). The treatment prescribed was followed by $77.1 \%$ of the patients in Group $A$ and by $75.3 \%$ of the patients in group B, showing that there was no significant statistical difference between groups. Both groups were similar regarding rescue medication required, whereas only $9.7 \%$ of the group A patients and $15.1 \%$ in group $B$ needed it. Both groups had similar frequency of adverse events: $30.2 \%$ in group $A$ and $36.6 \%$ in group $B$.

Patients which received a daily dose of 200mg at the end of

* Timasen ${ }^{\circledR}$ SR - ASTAMEDICA

Trabalho realizado no Centro de Terapia da Dor e Medicina Paliativa do Hospital Amaral Carvalho (Jau-SP) e Clínica de Ortopedia e Fraturas C.O.F. (Porto Alegre - RS)

1 - Chefe do Centro de Terapia da Dor e Medicina Paliativa do Hospital Amaral Carvalho de Jaú-SP.

2 - Professor Titular de Ortopedia e Traumatologia da Faculdade de Medicina da Universidade Federal do Rio Grande do Sul.

Endereço para correspondência: accafjau@uol.com.br / clinicaf@terra.com.br
Work performed at Centro de Terapia da Dor e Medicina Paliativa do Hospital Amaral Carvalho (Jau-SP) e Clínica de Ortopedia e Fraturas C.O.F. (Porto Alegre - RS)

1- Head, Center for Pain Therapy and Palliative Medicine, Amaral Carvalho Hospital of Jau, SP, Brazil

2 - Chairman of Orthopedics and Traumatology, Faculty of Medicine, Federa University of Rio Grande do Sul, RS, Brazil

Adress: accafjau@uol.com.br / clinicaf@terra.com.br 
Nos pacientes cuja dose final foi de $200 \mathrm{mg} /$ dia, a avaliação global da eficácia foi considerada boa e excelente pelos investigadores no grupo A em 86,7\% dos pacientes e no grupo B o resultado foi de $78,8 \%$. Os pacientes do grupo A consideraram a avaliação global da eficácia como boa e excelente em 88,9\% e no grupo B $78,8 \%$.

A tolerabilidade da droga foi considerada entre boa e excelente pelos investigadores no grupo A em $86 \%$ e no grupo B o resultado foi de $77,2 \%$. Os pacientes consideraram a tolerabilidade da droga como boa e excelente no grupo A em 77,4\% e no grupo B o resultado foi de $71,5 \%$.

Em conclusão, os dois grupos de tratamento foram estatisticamente semelhantes em relação a todos os parâmetros estudados, com exceção da intensidade da dor, a qual foi inicialmente maior no grupo $B$, sendo equivalente em ambos os grupos ao final do estudo. Houve uma tendência favorável, porém não significante, ao esquema terapêutico de titulação de doses.

Descritores: Dor crônica; Opiáceos; Tramadol.

\section{INTRODUÇÃO}

Pacientes que buscam serviços médicos devido à sintomas dolorosos representam 10 a 50\% de todas consultas médicas ${ }^{(19)}$. De 30 a 60\% das manifestações dolorosas, em adultos, ocorrem na forma crônica comprometendo o desempenho funcional e laborativo em maior ou menor grau destas, sem mencionar a queda da qualidade de vida e o impacto econômico-social que estas manifestações acarretam (2). Nos Estados Unidos, são gastos ao redor de 14 bilhões de dólares por ano só com a lombalgia ${ }^{(19)}$.

Desta forma, a dor tem sido entendida como um grave problema de saúde pública e, como tal, tem merecido os esforços de médicos especialistas e autoridades de muitos países. No Brasil, o Ministério da Saúde, no ano de 2002, preocupado e entendendo a magnitude da questão, criou o Programa Nacional de Educação e Assistência à Dor e Cuidados Paliativos para enfrentar o problema em nível nacional.

Por outro lado, os grandes avanços no conhecimento médico-científico da dor, desde a década de setenta até os dias de hoje não foram suficientes para que os portadores de dores crônicas merecessem avaliações corretas e tratamentos adequados. O mesmo acontecendo com o mito, extremamente arraigado, entre médicos e demais profissionais da saúde de que pacientes com dores intensas e particularmente aqueles com dores não relacionadas a canceres, não devem receber prescrições de morfínicos, sob risco de os transformarem em dependentes destas drogas ${ }^{(2,13)}$.

A droga cloridrato de tramadol, do grupo dos opiáceos, possui características especiais pois sua molécula inibe a recaptação da serotonina e da dopamina, além de exercer atividade opiácea sobre os receptores mi, kappa e delta, tendo pouca tendência de desenvolver tolerância e dependência física, mesmo em pacientes que façam uso dela por tempo prolonga$\mathrm{do}^{(2,4,7,16)}$.

Ultimamente, drogas como a metadona, levorfanol e tramadol são considerados como morfínicos de largo espectro, pois tem ações outras que são desejáveis em pacientes porta- the study had their global efficacy assessed as good and excellent by the investigators in $86.7 \%$ in group $A$ and $78.8 \%$ in group $B$. In group $A, 88.9 \%$ of the patients considered the global assessment of efficacy as good and excellent and in group B, 78.8\% of them did. Tolerability of the drug was considered good and excellent by the patients in group $A$ in $86 \%$ and in group $B$ the result was of $77,2 \%$.

In conclusion, both treatment groups were statistically similar regarding all assessed parameters, except for pain intensity, which was formerly higher in group $B$, and becoming equivalent in both groups at the end of the study. There was a favorable tendency, however non-significant, towards the titration dose group.

Key words: Chronicpain; Opiates; Tramadol.

\section{INTRODUCTION}

Patients seeking medical services due to painful symptoms represent 10 to $50 \%$ of all medical visits ${ }^{(19)}$. Between 30 and $60 \%$ of painful manifestations in adults occur in the chronic form, impairing the functional and labor performance, to some extent, not to mention the decline in quality of life and the social and economical impact caused by such manifestations (2). Approximately 14 billion dollars is spent each year in the United States to treat back pain alone ${ }^{(19)}$.

Therefore, pain has been understood as a severe public health problem and, as such, has deserved the efforts of medical experts and authorities in many countries. Concerned with the issue and aware of its magnitude, in 2002 the Brazilian Ministry of Health created the National Program for Education and Pain Assistance and Palliative Care, in order to face the problem at national level.

On the other side, the great advances in medical and scientific knowledge of pain from the 70s to date were not enough for those who suffer from chronic pain to receive correct evaluations and appropriate treatments. The same occurred with the myth, deeply rooted not only among physicians but also among other health professionals, that patients with intense pains, particularly those whose pains are not related to cancers, should not receive morphine-based prescriptions, at the risk of being converted into drug addicts ${ }^{(2,13)}$.

Tramadol hydrochloride is a drug of the opiate class with special characteristics, since its molecule inhibits serotonin and dopamine resorption, besides exerting an opiate activity on $m-, k$-, and $d$-receptors, with a reduced tendency to develop tolerance and physical dependence, even in patients who use it on a longterm basis $(2,4,7,16)$.

Lately, drugs such as methadone, levorphanol and tramadol are considered wide-spectrum morphinics, since their actions are beneficial to patients with mixed painful syndromes such as is the case with cancer patients, or even to patients with non- 
dores de síndromes dolorosas mistas, tais como nos cancerosos e mesmo dores crônicas não-oncológicas do tipo neuropáticas de grande intensidade ${ }^{(12)}$. Assim, o tramadol tem sido prescrito com freqüência para portadores de dores crônicas de origem não-oncológica e muitos trabalhos têm sido publicados na literatura internacional demonstrando a eficácia e segurança desta droga ${ }^{(1,3,5,6,8,10,11,17,18)}$

Sintomas desagradáveis, como náuseas, tonturas e vômitos, que acontecem apenas nos primeiros dias de uso da droga, eventualmente fazem com que os pacientes abandonem o tratamento, podendo ser evitados caso a prescrição seja de dosagens tituladas, como tem mostrado várias publicações ${ }^{(9,14)}$. Com base neste fato, a presente investigação foi proposta para comparar os dois esquemas posológicos, testando a tolerabilidade de ambos na dor crônica não-oncológica em um período de 15 dias.

\section{CASUÍSTICA E MÉTODOS}

Este estudo multicêntrico, de coorte e observacional teve como objetivo principal comparar os efeitos da titulação de doses no perfil de tolerabilidade do tramadol de liberação prolongada em pacientes com dor crônica não-oncológica. Os objetivos secundários foram: observar a incidência de eventos adversos à droga, a aderência ao tratamento, a utilização de medicação de resgate, o seguimento do tratamento prescrito, comparar a eficácia entre os dois grupos, avaliada pela escala visual analógica (EVA) e obter a avaliação global da eficácia e tolerabilidade segundo os investigadores e pacientes.

Foram recrutados para o estudo 189 pacientes de ambos os sexos e idades entre 14 e 75 anos, portadores de dor crônica não-oncológica há pelo menos três meses, de intensidade maior ou igual a 5 na escala visual analógica e com indicação de receber tramadol de liberação prolongada. Caso os pacientes estivessem recebendo nas duas últimas semanas algum analgésico, sua continuação deveria ser permitida sob critério médico. Os pacientes que puderam ser incluídos assinaram o termo de consentimento informado após concordarem em participar do estudo, sendo acompanhados por 20 médicos ortopedistas.

Os pacientes foram alocados no grupo A ou no Grupo B aleatoriamente, sendo que o grupo $A$ recebeu uma cápsula de $50 \mathrm{mg}$ de tramadol de liberação prolongada duas vezes ao dia por 3 a 7 dias, passando a receber duas cápsulas de 50 mg de tramadol de liberação prolongada duas vezes ao dia até o $15^{\circ}$ dia do estudo. O grupo B recebeu um cápsula de 100mg de tramadol de liberação prolongada durante os quinze dias dos estudo. Os pacientes poderiam usar tramadol em gotas, como medicação de resgate, caso houvesse escape da dor nos intervalos entre as administrações.

Os critérios de exclusão foram: apresentar quadro de intoxicação por opiáceos, hipnóticos, álcool, ou analgésico de ação central, estar tomando inibidores da monoaminoxidase, hiperssensibilidade aos opiáceos, disfunção renal ou hepática grave, pressão intracraniana elevada, diminuição do nível de consciência, choque, risco de convulsões, depressão respiratória instalada, secreção brônquica excessiva, tratamento concomitante com fármacos de atuação no sistema nervoso central e, sendo mulheres, não poderiam estar amamentando.

Uma vez admitidos no estudo, foi avaliada na Visita 1 (V1) a oncologic chronic pains such as high-intensity neuropathic pains ${ }^{(12)}$. For this reason, tramadol has been frequently prescribed to patients with non-oncologic chronic pains; also, a number of papers have been published all over the world showing the efficacy and safety of this drug $(1,3,5,6,8,10,11,17,18)$.

Unpleasant symptoms such as nausea, dizziness and vomiting, that are present in the first days of drug use only, will occasionally make patients drop out the therapy, although they might be avoided with by titrating the prescription dose, as shown by several authors ${ }^{(9,14)}$. Based on this fact, this investigation was proposed to compare both dose regimens by testing their tolerability in non-oncologic chronic pain during a 15-day period.

\section{CASES AND METHODS}

The primary objective of this multicenter, cohort, and observational study was to compare the effects of dose titration on the tolerability profile of sustained-release tramadol in patients with non-oncologic chronic pain. The secondary objectives were to observe the incidence of drug-emergent side effects, treatment adherence, use of rescue medication, compliance with the prescribed medication, comparison of inter group efficacy as assessed by the visual analog scale (VAS), and obtain the global efficacy and tolerability assessment by both investigators and patients.

The study included 189 patients of both sexes, in the 14-75 year age group, with non-oncologic chronic pain for at least three months rated equal or higher than 5 on the VAS, and with indication to receive sustained-release tramadol. In case the patients had been on some analgesic during the last two weeks, its continuation was allowed at the physician's discretion. After agreeing in participating in the study, each eligible patient signed an informed consent form and was monitored by 20 orthopedists.

Patients were randomly assigned either to Group A or B. Group A received one 50-mg capsule of sustained-release tramadol b.i.d. for 3 to 7 days, followed by two 50-mg capsules of sustained-release tramadol b.i.d. until Day 15 of the study. Group $B$ received one 100-mg capsule of sustained-release tramadol throughout the fifteen days of the study. As rescue medication, patients were allowed to take tramadol drops, in case of recurrence of pain between administrations.

Exclusion criteria were intoxication by opiates, use of hypnotics, use of alcohol or central action analgesics, being on monoaminoxidase inhibitors, hypersensitivity to opiates, severe renal or liver dysfunction, high intracranial pressure, decrease in the awareness level, shock, risk of convulsion, onset of respiratory depression, excess bronchial secretion, concomitant therapy with drugs acting on the central nervous system; in the case of women, breastfeeding was not accepted.

After being included in the study, on Visit 1 (V1) all patients scored their pains using a 100-mm visual analog scale (VAS) ranging from 0 (absence of pain) to 10 (the most intense pain possible); also, the type of chronic pain was recorded, as well as concomitant drugs used.

On Day 15 (Visit 2), pain intensity was recorded using the 
pontuação do escore da dor em uma escala visual analógica de 100mm: 0 (ausência de dor) a 10 (a dor mais intensa possível), registrado o tipo de dor crônica e as medicações concomitantes.

No décimo quinto dia de tratamento (V2), foram registrados a intensidade da dor através da pontuação do escore da dor na escala visual analógica de $100 \mathrm{~mm}$ e medicações concomitantes. O teste estatístico foi realizado na população PP (per protocol), isto é, nos pacientes que completaram o tratamento de acordo com o protocolo.

A aderência dos pacientes ao tratamento foi avaliada e, quando insuficiente, o número de cápsulas utilizado foi registrado, bem como a razão da baixa aderência. Foi realizado o registro do uso da medicação de resgate, quando necessário, e também os eventos adversos.

Ao final do estudo, tanto os pesquisadores como os pacientes avaliaram globalmente a eficácia e a tolerabilidade do tratamento com o tramadol de acordo com a seguinte classificação: muito boa, boa, moderada e ruim.

$\mathrm{Na}$ análise estatística, foram utilizados os testes paramétricos: Teste t de Student para a comparação entre os grupos da idade; análise de variância ("two-way") para a comparação simultânea das médias intra-grupos e entre grupos do parâmetro intensidade de dor na escala visual analógica. Os testes nãoparamétricos empregados foram Teste Qui-quadrado para a comparação entre grupos de dados demográficos, avaliação do tipo de dor, uso de medicações concomitantes e de resgate, eventos adversos, avaliação global da eficácia e tolerabilidade.

Todos os testes foram bicaudais e o nível de significância adotado foi de $5 \%$.

\section{RESULTADOS}

Dos 189 pacientes incluídos neste estudo, foram alocados no grupo A 96 pacientes e grupo B 93 pacientes. Ao final do estudo, 116 pacientes concluíram-no de acordo com a posologia estabelecida pelo protocolo, sendo então analisados estatisticamente como população "per protocol" (PP). Os pacientes que não completaram o estudo por eventos adversos relacionados à medicação foram considerados na casuística total da avaliação estatística (PP).

Os pacientes que não completaram o estudo por terem abandonado o tratamento, não retornando à visita 2 (Dia 15+2), ou por não terem tomado corretamente a medicação do estudo, foram considerados para a avaliação da tolerabilidade do tramadol de liberação prolongada, formando a população "intent to treat" (ITT).

A Tabela 1 descreve as características demográficas de cada grupo de tratamento.

A Tabela 2 relaciona os tipos de dores não-oncológicas dos dois grupos registradas na V1 (médias e desvios-padrão). Observou-se que o tipo de dor mais freqüente no grupo $A$ foi músculo-esquelética e no grupo B o tipo osteoarticular.

A utilização de analgésicos concomitantes foi semelhante nos dois grupos de tratamento, tanto na proporção de pacientes que utilizaram-nos como no número de medicamentos em uso.

A intensidade da dor foi avaliada a cada visita, através da above-mentioned VAS, as well as any concomitant drugs used. The statistical test was applied to the PP (per protocol) population, that is, to patients who completed the treatment as per the protocol.

The compliance parameter was evaluated and, if insufficient, the number of capsules taken was recorded, as well as the reason for the poor compliance. The use of rescue medication when necessary - was also recorded, as well as the adverse events.

At the end of the study, investigators and patients globally evaluated the efficacy and tolerability of the treatment with trama$\mathrm{dol}$ according to the following ratings: very good, good, moderate, and poor.

For the statistical analysis the following parametric tests were employed: Student's t test for an inter group comparison of age; two-way variance analysis to simultaneously compare the average intensity pain parameter inter-and intra groups using the VAS. The non-parametric tests employed were the $c^{2}$ test to compare inter group demographic data, evaluation of the type of pain, use of concomitant and rescue drugs, adverse events, and global efficacy and tolerability assessment.

All were two-tailed tests and the significance level adopted was $5 \%$.

\section{RESULTS}

Ninety-six of the 189 patients included in this study were assigned to Group A and 93 to Group B. 116 patients completed the study on the dose regimen established as per the protocol and were statistically analyzed as a per protocol (PP) population. Patients who did not complete the study because of drug-related adverse events were taken into account in the total number of cases in the statistical evaluation (PP).

Patients who dropped out, and therefore did not complete the study and did not return for Visit 2 (Day 15+2), or showed lack of compliance, were included in the evaluation of tolerability of sustained-release tramadol, forming the "intention-to-treat" (ITT) population.

Table 1 describes the demographic characteristics of each treatment group.

Table 2 relates the types on non-oncologic pains in both groups, recorded at Visit 1 (averages $\pm S D$ ). The most frequent type of pain observed in Group A was the musculoskeletal pain, and osteoarticular pain in Group B.

The concomitant use of analgesics was similar in the two treatment groups, both as regards the proportion of patients who used them, and the number of drugs being used.

Pain intensity was evaluated at each visit using a 100-cm long VAS. A highly significant improvement was noticed in both groups, with a $67 \%$ reduction in pain intensity. On the other side, is should be emphasized that Group A presented initially a significantly lower average as compared to Group B, due to the fact that Group 
As manifestações gastrointestinais foram os eventos adversos mais comumente relatados, como náuseas e vômitos. Tonturas e vertigens foram também relatadas com freqüência (Tabela 7).

Naqueles pacientes que terminaram o estudo com a dose diária de 200mg ( $n=116)$, a avaliação global da eficácia foi classificada pelos investigadores como sendo excelente em $51,1 \%$ e boa em $35,6 \%$ no grupo A. No grupo B, a classificação como excelente foi de $39,4 \%$ e boa em $39,4 \%$. A comparação estatística entre grupos não atingiu significância (Tabela 8, Gráfico 3).

Estes pacientes classificaram a avaliação global da eficácia como excelente em $53,3 \%$ e boa em $35,6 \%$ no grupo A. Esta classificação foi excelente em $39,4 \%$ e boa em $39,4 \%$ dos pacientes do grupo B ( Tabela 9, Gráfico 4).

As opiniões dos investigadores e dos pacientes foram bastante semelhantes, havendo coincidência entre as proporções de excelente e boa.

Para os 65 pacientes que terminaram o estudo com dose diária £ 100mg, os investigadores julgaram excelente a eficácia do tratamento do grupo A em $47,7 \%$ e boa em $31,8 \%$ dos casos. No grupo B esta classificação foi de $47,4 \%$ como excelente e boa em $31,6 \%$ dos casos (Tabela 10, Gráfico 5).

Segundo a opinião dos pacientes, o tratamento com tramadol sob o esquema $A$ foi excelente em $54,5 \%$ e bom em $25 \%$ dos casos e, sob o esquema B, foi excelente em $42,1 \%$ e bom em $26,3 \%$ dos casos (Tabela 11, Gráfico 6). Não houve diferença significante entre os grupos. Na opinião dos pacientes, a proporção de excelente foi maior no grupo $A$ em relação ao B, entretanto, não houve discordância em relação à opinião do investigador.

Na avaliação global da tolerabilidade foi considerada a

\begin{tabular}{|c|c|c|c|c|c|}
\hline \multirow{2}{*}{ Medicação de Resgate: } & \multicolumn{2}{|c|}{ Grupo A } & \multicolumn{2}{|c|}{ Grupo B } & \multirow{2}{*}{$\begin{array}{l}\text { Comparação } \\
\text { estatística** }\end{array}$} \\
\hline & $\mathrm{N}^{0}$ & $\%$ & $N^{0}$ & $\%$ & \\
\hline Sim & 9 & 9.7 & 14 & 15,1 & \multirow{2}{*}{ n.s. ** } \\
\hline Não & 84 & 90,3 & 79 & 84,9 & \\
\hline Total & 93 & 100,0 & 93 & 100,0 & \\
\hline Sem informação & 3 & & - & & \\
\hline " teste Qui-quadrado & $=$ nã & gnificativ & & & \\
\hline
\end{tabular}

Tabela 5 - Necessidade de medicação de resgate Table 5 - Need of rescue medication

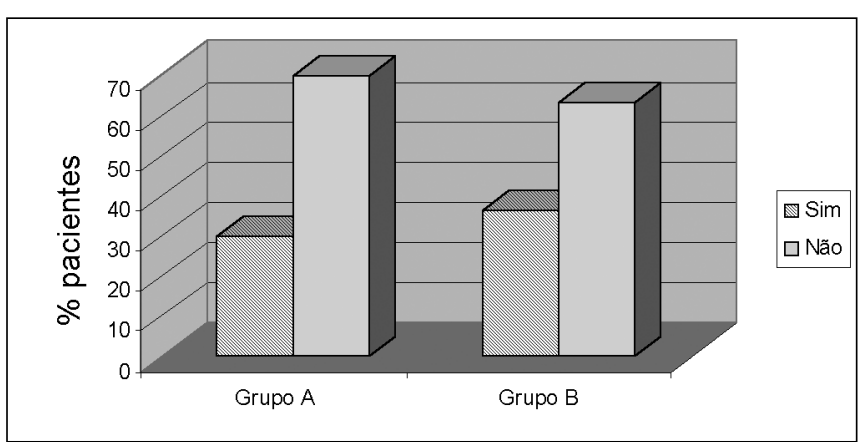

Gráfico 2 - Incidência de eventos adversos Graph 2 - Incidence of adverse events

\begin{tabular}{|c|c|c|c|c|c|}
\hline \multirow{2}{*}{$\begin{array}{l}\text { Intervalo (dias) entre o início } \\
\text { do tratamento e a ocorrência } \\
\text { do evento adverso }\end{array}$} & \multicolumn{2}{|c|}{ Grupo A } & \multicolumn{2}{|c|}{ Grupo B } & \multirow{2}{*}{$\begin{array}{l}\text { Comparação } \\
\text { estatística* }\end{array}$} \\
\hline & $N^{\circ}$. & $\%$ & $N^{0}$. & $\%$ & \\
\hline 1 & 17 & 58,6 & 25 & 73,5 & \multirow{8}{*}{ n.s. ${ }^{* *}$} \\
\hline 2 & 3 & 10,3 & 5 & 14,7 & \\
\hline 3 & 4 & 13,8 & 3 & 8,8 & \\
\hline 4 & 1 & 3,4 & 0 & 0,0 & \\
\hline 5 & 1 & 3,4 & 1 & 2,9 & \\
\hline 7 & 1 & 3,4 & 0 & 0,0 & \\
\hline 9 & 1 & 3,4 & 0 & 0,0 & \\
\hline 15 & 1 & 3,4 & 0 & 0,0 & \\
\hline Total & 29 & 100,0 & 34 & 100,0 & \\
\hline
\end{tabular}

Tabela 6 - Intervalo (dias) entre o início do tratamento e a ocorrência do evento adverso

Table 6 - Number of days between the beginning of treatment and the onset of the adverse event

\begin{tabular}{|l|c|c|c|}
\hline Eventos adversos & Grupo A & Grupo B & Total \\
\hline Náuseas & 11 & 8 & 19 \\
\hline Tontura & 9 & 12 & 21 \\
\hline Vômitos & 3 & 6 & 9 \\
\hline Mal estar & 2 & 4 & 6 \\
\hline Sonolência & 2 & 2 & 4 \\
\hline Sudorese & 2 & 0 & 2 \\
\hline Confusão mental & 0 & 1 & 1 \\
\hline Outros & 16 & 24 & 40 \\
\hline Total & $\mathbf{4 5}$ & $\mathbf{5 7}$ & $\mathbf{1 0 2}$ \\
\hline
\end{tabular}

Tabela 7 - Eventos adversos

Table 7 - Adverse events

\begin{tabular}{|c|c|c|c|c|c|}
\hline \multicolumn{6}{|c|}{ Pacientes com dose final de $200 \mathrm{mg} /$ dia $(\mathrm{n}=116 \mathrm{pac})$} \\
\hline & 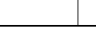 & & - & & \\
\hline \multirow{2}{*}{ Opinião do Investigador: } & \multicolumn{2}{|c|}{ Grupo A } & \multicolumn{2}{|c|}{ Grupo B } & \multirow{2}{*}{$\begin{array}{l}\text { Comparação } \\
\text { Estatística* }\end{array}$} \\
\hline & $N^{\circ}$ & $\%$ & No. & & \\
\hline Excelente & 23 & 51,1 & 28 & 39,4 & \multirow{4}{*}{ n.s.* } \\
\hline Boa & 16 & 35,6 & 28 & 39,4 & \\
\hline Moderada & 4 & 8,9 & 10 & 14,1 & \\
\hline \multirow[t]{2}{*}{ Ruim } & 2 & 4,4 & 5 & 7,0 & \\
\hline & & & & & \\
\hline Total & 45 & 100,0 & 71 & 100,0 & \\
\hline t teste Qui-quadrado & 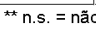 & ativo & & & \\
\hline
\end{tabular}

Tabela 8 - Avaliação global da eficácia na opinião do investigador Table 8 - Global efficacy assessment by investigator rated excellent in $51.1 \%$ and good in $35.6 \%$ of the cases in Group A. In Group B, these values were $39.4 \%$ and $39.4 \%$, respectively. No significant differences were found in the inter group statistical comparison (Table 8, Graph 3).

These patients rated the global efficacy as excellent in 53.3\% of the cases and good in $35.6 \%$ of the cases in Group A. In Group $B$ these values were $39.4 \%$ and $39.4 \%$, respectively (Table 9, Graph 4).

The assessments by investigators and patients were rather similar, and the excellent and good proportions coincided.

For the 65 patients who completed the study on daily doses $£ 100 \mathrm{mg}$, investigators rated the efficacy in Group A as excellent in $47.7 \%$ of cases and good in $31.8 \%$ of cases. In Group B these values were of $47.4 \%$ and $31.6 \%$, respectively (Table 10 , Graph 5).

Treatment with tramadol under the $A$ regimen was rated by patients as excellent in $54.5 \%$ of cases and good in 25\% of cases; under the $B$ regimen, these values were $42.1 \%$ and $26.3 \%$, respectively (Table 11, Graph 6). No significant differences were found between groups. Patients rated more cases as excellent in Group A as compared to Group $B$, although such ratings agreed with those of the investigator.

The global tolerability assessment was based on the ITT population, which included 189 patients. According to the investigator, treatment in Group A was rated excellent in $44.1 \%$ and good in $41.9 \%$ of cases. In Group B, these values were $43.5 \%$ and $33.7 \%$, respectively (Table 12, Graph 7).

Patients rated tolerability as excellent in $41.9 \%$ of cases and good in $35.5 \%$ of cases in Group A. These values were respectively $39.6 \%$ and $31.9 \%$ in Group B. (Table 13, Graph 8) 
população ITT, com 189 pacientes. Na opinião dos investigadores, o tratamento no grupo A foi considerado como excelente em $44,1 \%$ e boa em $41,9 \%$ dos casos. No grupo B, os investigadores consideraram-na excelente em 43,5\% e boa em $33,7 \%$ dos casos. (Tabela 12, Gráfico 7)

Já na opinião dos pacientes, a tolerabilidade foi considerada excelente em 41,9\% e como boa em $35,5 \%$ dos casos no grupo A. A tolerabilidade da droga foi considerada excelente em $39,6 \%$ e boa em $31,9 \%$ dos casos no grupo B. (Tabela 13, Gráfico 8)

\section{DISCUSSÃO}

Em nosso estudo, observamos que a redução da intensidade da dor foi altamente significativa nos dois grupos de tratamento quando comparou-se a média da EVA inicial com a final, confirmando dados da literatura quanto à eficácia da tramadol $^{(1,3,5,6,10,17,18)}$.

Entretanto, não houve diferença estatisticamente significativa entre os grupos com relação à freqüência de eventos adversos, necessidade de medicação de resgate, aderência ao tratamento prescrito, avaliação global da eficácia e da tolerabilidade, embora uma discreta tendência favorável, sem significado estatístico, possa ser observada com a titulação de doses no grupo A. Além disso, é provável que houvesse sido encontrada significância estatística nos parâmetros estudados caso o tamanho da amostra fosse ampliado.

A freqüência de eventos adversos foi maior nos primeiros dias da administração de tramadol de liberação prolongada, confirmando dados da literatura com relação à classe dos opiói$\operatorname{des}^{(1,3,5,7,10,16,18)}$. Segundo alguns autores, este fato pode ser minimizado utilizando-se doses menores nos primeiros dias e posteriormente titulando-se até

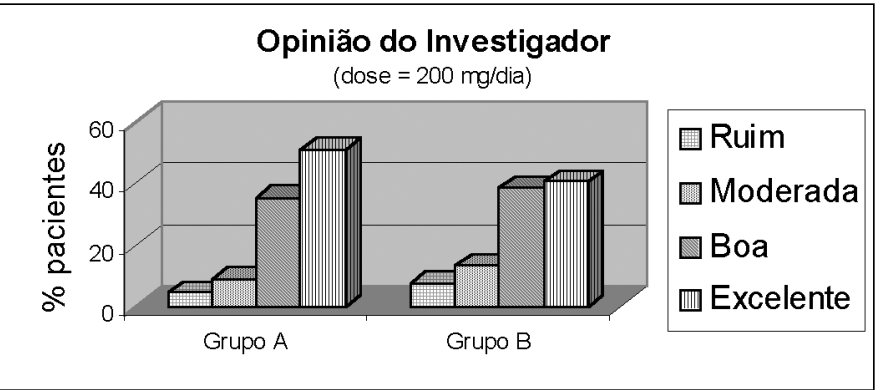

Gráfico 3 - Avaliação global da eficácia na opinião do investigador Graph 3 - Global efficacy assessment by investigator

\begin{tabular}{|c|c|c|c|c|c|}
\hline \multirow{2}{*}{ Opinião do Paciente: } & \multicolumn{2}{|c|}{ Grupo A } & \multicolumn{2}{|c|}{ Grupo B } & \multirow{2}{*}{$\begin{array}{l}\text { Comparação } \\
\text { estatística* }^{*} \\
\end{array}$} \\
\hline & $\mathrm{N}^{0}$ & $\%$ & $\mathrm{~N}^{\circ}$ & $\%$ & \\
\hline Excelente & 24 & 53,3 & 28 & 39,4 & \multirow{4}{*}{ n.s. ${ }^{\star \star}$} \\
\hline Boa & 16 & 35,6 & 28 & 39,4 & \\
\hline Moderada & 2 & 4,4 & 7 & 9,9 & \\
\hline Ruim & 3 & 6,7 & 8 & 11,3 & \\
\hline Total & 45 & 100,0 & 71 & 100,0 & \\
\hline
\end{tabular}

Tabela 9 - Avaliação global da eficácia na opinião dos pacientes Table 9 - Global efficacy assessment by patients

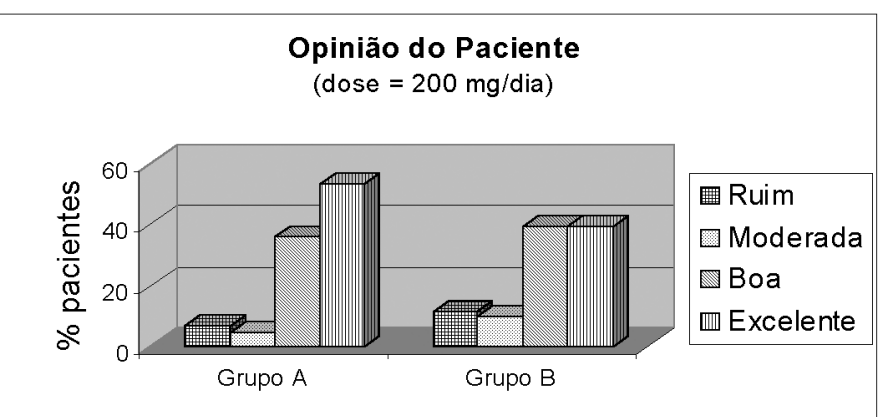

Gráfico 4 - Avaliação global da eficácia na opinião dos pacientes Graph 4 - Global efficacy assessment by patients

\begin{tabular}{|c|c|c|c|c|c|}
\hline \multicolumn{6}{|c|}{ Pacientes com dose final de 100 ou $50 \mathrm{mg} /$ dia $(\mathrm{n}=65 \mathrm{pac})$} \\
\hline \multirow{2}{*}{ Opinião do Investigador: } & \multicolumn{2}{|c|}{ Grupo A } & \multicolumn{2}{|c|}{ Grupo B } & \multirow{2}{*}{\begin{tabular}{|l} 
Comparação \\
estatistica**
\end{tabular}} \\
\hline & No. & $\%$ & No. & & \\
\hline Excelente & 21 & 47,7 & 9 & 47,4 & \multirow{4}{*}{ n.s. ${ }^{* *}$} \\
\hline Boa & 14 & 31,8 & 6 & 31,6 & \\
\hline Moderada & 2 & 4,5 & 2 & 10,5 & \\
\hline Ruim & 7 & 15,9 & 2 & 10,5 & \\
\hline Total & 44 & 100,0 & 19 & 100,0 & \\
\hline Sem informaçăo & 1 & & 1 & & \\
\hline
\end{tabular}

Tabela 10 - Avaliação global da eficácia na opinião do investigador Table 10 - Global efficacy assessment by investigator

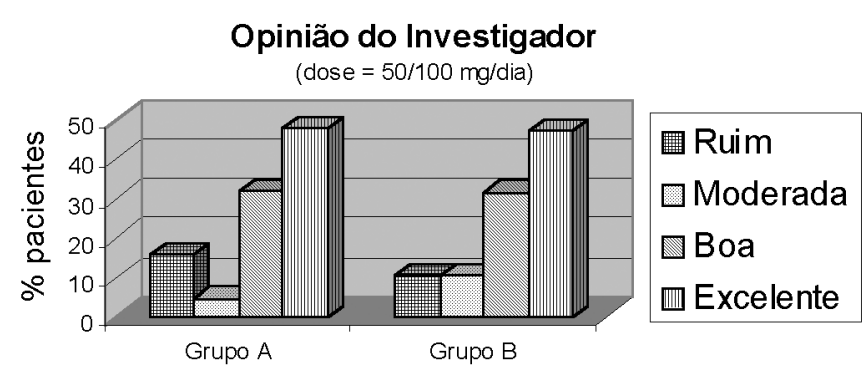

Gráfico 5 - Avaliação global da eficácia na opinião do investigador Graph 5 - Global efficacy assessment by investigator

\section{DISCUSSION}

In our study we observed that the reduction in pain intensity was highly significant in both treatment groups when the average VAS initial score was compared to the final VAS score, thus confirming data on the efficacy of tramadol found in literature ${ }^{(1,3,5,6,10,17,18)}$.

However, no statistically significant differences were found between groups as regards the frequency of adverse events, need of rescue medication, treatment adherence and global efficacy and tolerability assessment, although a slightly favorable, but not statistically significant tendency was observed after dose titration in Group $A$. Also, it is likely that, if the sample was extended, a statistical significance could be found in the parameters.

The frequency of adverse events was higher during the first days of administration of sustained-release tramadol, confirming data on literature as regards the opiate class $(1,3,5,7,10,16,18)$. According to some authors, this fact may be minimized by using lower doses in the first few days and, thereafter, dose titrating up to the analgesic dose ${ }^{(0,14)}$. It is important noticing that in 13 cases investigators deemed the causal relationship of adverse events unlikely. In this way, the proportion of patients presenting adverse events would be $16 \%$ lower than the proprotion considered without excluding the causality variable. It is worth emphasizing the clinical significance of the favorable clinic profile of adverse events in the group where doses were titrated.

The investigators in this study did not observe the occurrence of obstipation, which is rather frequent with any analgesic of the opiate class ${ }^{(2)}$. The cases of dizziness 
a dose analgésica ser atingida ${ }^{(9,14)}$. É importante observarmos que houve 13 casos onde a relação causal dos eventos adversos foi considerada pelos investigadores como improvável. Deste modo, a percentagem de pacientes que apresentaram eventos adversos seria 16\% menor que aquele considerado sem a exclusão da variável de causalidade. É importante ressaltar a significância clínica do perfil favorável de eventos adversos do grupo em que a titulação de doses foi realizada.

Neste estudo, os investigadores não observaram a ocorrência de obstipação, o que é muito freqüente com qualquer analgésico do grupo dos opiáceos(2). Os casos de tontura relatados por 9 pacientes do grupo A e 12 pacientes do grupo B no início do tratamento podem ser explicados pelos efeitos serotoninérgicos do tramadol ${ }^{(7,16)}$. A sonolência, outra ocorrência comum em pacientes fazendo o uso de morfínicos $^{(2)}$, manifestou-se apenas em 2 pacientes do grupo $A$ e 2 do grupo $B$ e isto poderia se explicado pela inexistência de picos plasmáticos elevados quando são prescritas drogas de liberação prolongada.

Com relação à aderência ao tratamento prescrito, é importante observar que a meIhora da dor foi relatada como a principal razão para o não cumprimento do esquema terapêutico previamente estabelecido. É possível que esta proporção de pacientes seja ainda maior se considerarmos que, em alguns casos, não foi possível aferir adequadamente os verdadeiros motivos da nãoaderência.

O tempo de utilização do tramadol de liberação lenta pelos pacientes, neste estudo, foi curto. Portanto, não

\begin{tabular}{|c|c|c|c|c|c|}
\hline \multirow{2}{*}{ Opinião do Paciente: } & \multicolumn{2}{|c|}{ Grupo A } & \multicolumn{2}{|c|}{ Grupo B } & \multirow{2}{*}{\begin{tabular}{|l|} 
Comparação \\
estatística**
\end{tabular}} \\
\hline & $N^{0}$. & $\%$ & No & $\%$ & \\
\hline Excelente & 24 & 54,5 & 8 & 42,1 & \multirow{4}{*}{ n.s. ${ }^{* *}$} \\
\hline Boa & 11 & 25,0 & 5 & 26,3 & \\
\hline Moderada & 1 & 2,3 & 4 & 21,1 & \\
\hline Ruim & 8 & 18,2 & 2 & 10,5 & \\
\hline Total & 44 & 100.0 & 19 & 100,0 & \\
\hline Sem informação & 1 & & 1 & & \\
\hline
\end{tabular}

Tabela 11 - Avaliação global da eficácia na opinião dos pacientes Table 11 - Global efficacy assessment by patients

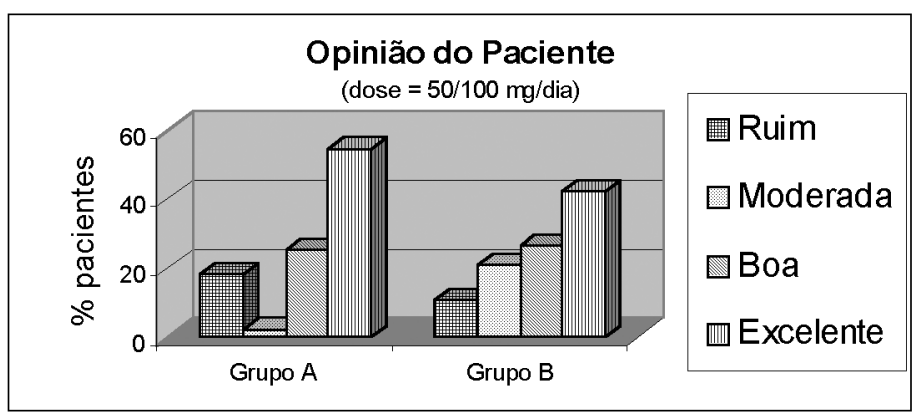

Gráfico 6 - Avaliação global da eficácia na opinião dos pacientes Graph 6 - Global efficacy assessment by patients

\begin{tabular}{|c|c|c|c|c|c|}
\hline \multirow{2}{*}{$\begin{array}{l}\text { Opinião do } \\
\text { Investigador: }\end{array}$} & \multicolumn{2}{|c|}{ Grupo A } & \multicolumn{2}{|c|}{ Grupo B } & \multirow{2}{*}{$\begin{array}{l}\text { Comparação } \\
\text { Estatística* }^{*}\end{array}$} \\
\hline & $N^{0}$ & $\%$ & $N^{0}$ & $\%$ & \\
\hline Excelente & 41 & 44,1 & 40 & 43,5 & \multirow{4}{*}{ n.s. ** } \\
\hline Boa & 39 & 41,9 & 31 & 33,7 & \\
\hline Moderada & 7 & 7,5 & 9 & 9,8 & \\
\hline Ruim & 6 & 6,5 & 12 & 13,0 & \\
\hline Total & 93 & 100,0 & 92 & 100,0 & \\
\hline Sem informação & 3 & & 1 & & \\
\hline
\end{tabular}

Tabela 12 - Avaliação global da tolerabilidade na opinião do investigador Table 12 - Global tolerability assessment by investigator

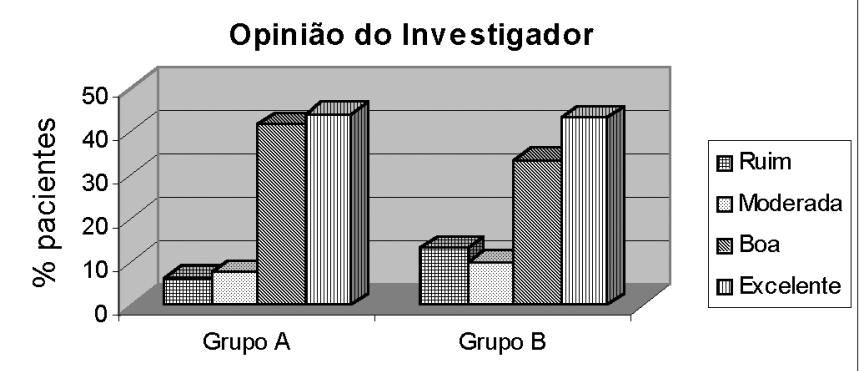

Gráfico 7- Avaliação global da tolerabilidade na opinião do investigador Graph 7 - Global tolerability assessment by investigator

\begin{tabular}{|c|c|c|c|c|c|}
\hline \multirow[b]{2}{*}{ Opinião do Paciente: } & \multicolumn{2}{|c|}{ Grupo A } & \multicolumn{2}{|c|}{ Grupo B } & \multirow{2}{*}{$\begin{array}{l}\text { Comparação } \\
\text { Estatística* }\end{array}$} \\
\hline & No. & $\%$ & $N^{0}$ & & \\
\hline Excelente & 39 & 41,9 & 36 & 39,6 & \multirow{4}{*}{ n.s. ** } \\
\hline Boa & 33 & 35,5 & 29 & 31,9 & \\
\hline Moderada & 14 & 15,1 & 13 & 14,3 & \\
\hline Ruim & 7 & 7,5 & 13 & 14,3 & \\
\hline Total & 93 & 100.0 & 91 & 100,0 & \\
\hline Sem informação & 3 & & 2 & & \\
\hline
\end{tabular}

Tabela 13 - Avaliação global da tolerabilidade na opinião dos pacientes Table 13 - Global tolerability assessment by patients reported by 9 patients in Group $A$ and 12 patients in Group $B$ at the beginning of the treatment may be explained by the serotoninergic effects of tramadol (7,16). Drowsiness, which is also common in patients on morphinics (2), manifested in only 2 patients in Group A and 2 patients in Group B, and this might be explained by the lack of high plasma peaks in cases where sustained-release drugs are prescribed.

As to treatment adheren$c e$, it is important to notice that pain improvement was reported as the main reason why patients did not comply with the previously established therapeutic regimen. Most likely, this proportion of patients is even greater if we consider that in some cases it was not possible to properly determine the actual reasons for noncompliance.

In this study, the period of use of sustained-release tramadol by patients was rather short. Therefore, no conclusions can be reached as regards tolerance development and addictive behavior.

The use of progressive dose titration and the introduction of drugs such as tramadol hydrochloride in the sustained-release formulation can minimize the difficulties found in the beginning of therapy by providing better tolerability and compliance to patients requiring opiates to control their painful syndromes.

\section{CONCLUSION}

Both dose regimens of sustained-release tramadol hydrochloride showed to be similar in both treatment groups as regards efficacy 
poderemos tirar conclusões a respeito do desenvolvimento de tolerância e comportamento de adição.

A observância da titulação progressiva das doses e a utilização de drogas na formulação de liberação prolongada, como o cloridrato de tramadol podem minimizar as dificuldades do início da terapêutica, oferecendo maior tolerabilidade e aderência aos pacientes que necessitem de opiáceos para controlar suas síndromes dolorosas.

\section{CONCLUSÃO}

Os dois esquemas posológicos do cloridrato de tramadol de liberação prolongada demonstraram ser semelhantes nos dois grupos de tratamento em relação à eficácia e tolerabilidade, necessidade de medicação de resgate e aderência dos pacientes. A intensidade da dor, a qual foi inicialmente maior no grupo $B$, demonstrou atingir valores equivalentes em ambos os grupos ao final do estudo. Houve uma tendência favorável, porém não significante, ao esquema terapêutico de titulação de doses.

\section{AGRADECIMENTOS:}

Dr. Milton Possedente, Dr. José Maurício Dias, Dr. Lourival M. O. Gomes, Dr. Carlos Augusto Cauchiolli, Dr. Jesus Gutierres, Dr. Wallace Marion, Dra. Rosilene Castiglia, Dr. Gerson de Sá Tavares Filho, Dr. Egídio Paulo Oliveira Fré, Dr. Paulo José Scherner, Dr. Rui Alberto Ribeiro de Oliveira, Dr. Erno Thober, Dr. Geraldo Costa, Dr. Luiz Eduardo Hirata, Dr. Bernardino Leal de Quadros Júnior, Dr. Celestino de Oliveira Souza, Dr. José Cândido G. da Costa, Dr. João de Souza Gaspar e Dr. Domingos Ferreira Cardoso.

\section{REFERÊNCIAS BIBLIOGRÁFICAS}

1. Andersen $\mathrm{S}$, Leikersfeldt $\mathrm{G}$. Management of chronic non-malignant pain. $\mathrm{Br} J$ Clin Pract 50:324-330, 1996.

2. Andrade Filho ACC. Dor - diagnóstico e tratamento. São Paulo: Roca; 2001. p 43-44, 247-254, 265-268

3. Bamigbade TA, Langford RM. The clinical use of tramadol hydrochloride. Pain Rev 5:155-182, 1998

4. Barth H, Durra S, Geirtz H, Goroll D, Flohe L. Long-term administration of the centrally acting analgesic tramadol did not induce dependence or tolerance. Pain Suppl 4: S231. 1987

5. Cossmann M, Wilsmann KM. Behandlung länger andauernder schmerzsyndrome. Beurteilung der Wirkung und Verträglichkeit von Tramadol (tramal) bei mehrmaliger Gabe. Münch Med Wochenschr 129:851-854, 1987.

6. Katz WA. Pharmacology and clinical experience with tramadol in ostheoarthritis. Drugs 52(Suppl):39-47, 1996

7. Lee CR, McTavish D, Sorkin EM. Tramadol: A preliminary review of its pharmacodynamic and pharmacokinetic, properties and therapeutic potential in acute and chronic pain stages. Drugs 46:313-340, 1993

8. Nossol S, Schwarzbold M, Stadler T. Treatment of pain with sustained-release tramadol 100, 150, $200 \mathrm{mg}$ : results of a post-marketing surveillance study. Int J Clin Pract 52:115-121, 1998.

9. Petrone D, Kamin M, Olson W. Slowing the titration rate of Tramadol $\mathrm{HCl}$ reduces the incidence of discontinuation due to nausea and/or vomiting: a double-blind randomized trial. J Clin Pharm Ther 24:115-123, 1999.

\section{ACKNOWLEDGEMENTS:}

Dr. Milton Possedente, Dr. José Maurício Dias, Dr. Lourival M. O. Gomes, Dr. Carlos Augusto Cauchiolli, Dr. Jesus Gutierres, Dr. Wallace Marion, Dr. Rosilene Castiglia, Dr. Gerson de Sá Tavares Filho, Dr. Egídio Paulo Oliveira Fré, Dr. Paulo José Scherner, Dr. Rui Alberto Ribeiro de Oliveira, Dr. Erno Thober, Dr. Geraldo Costa, Dr. Luiz Eduardo Hirata, Dr. Bernardino Leal de Quadros Júnior, Dr. Celestino de Oliveira Souza, Dr. José Cândido G. da Costa, Dr. João de Souza Gaspar, and Dr. Domingos Ferreira Cardoso. and tolerability, need for rescue medication, and compliance. Pain intensity, which initially was higher in Group $B$, has shown to reach equivalent values in both groups at the end of the study. A favorable, although non-significant trend exists towards the dose-titration therapeutic regimen.

10. Raber M, et al. Analgesic efficacy and tolerability of tramadol $100 \mathrm{mg}$ sustainedrelease capsules in patients with moderate to severe chronic low back pain. Clin Drug Invest 17: 415-423, 1999.

11. Radbruch L, Grond S, Lehmann KA. A risk-benefit assessment of tramadol in the management of pain. Drug Saf 15:8-29, 1996.

12. Ready LB, Edwards WT. Tratamento da dor aguda. Rio de Janeiro: Revinter; 1994. p.13-18. (Publicação da IASP)

13. Richter W, Barth H, Flohé L, Giertz H. Clinical investigation on the development of dependence during oral therapy with tramadol. Arzneimittelforschung 35:17421744, 1985.

14. Ruoff GE. Slowing the initial titration rate of tramadol improves tolerability. Pharmacotherapy 19:88-93, 1999

15. Schnitzer TJ. Non-NSAID pharmacologic treatment options for the management of chronic pain. Am J Med 105:45S-52S, 1998

16. Scott LJ, Perry CM. Tramadol. A review of its use in perioperative pain. Drugs 60:139-176, 2000.

17. Shipton EA. Tramadol - Present and future. Anaesth Intensive Care 28:363-374, 2000.

18. Sorge J, et al. Comparison of the analgesic efficacy and tolerability of tramadol $100 \mathrm{mg}$ sustained-release tablets and tramadol $50 \mathrm{mg}$ capsules for the treatment of chronic low back pain. Clin Drug Invest 14:157-164, 1997

19. Teixeira MJ, Marcon RM, Rocha RO, Figueiró JAB. Epidemiologia da dor. In: Teixeira MJ, Figueiró JAB. DOR - Epidemiologia, fisiopatologia, avaliação, síndromes dolorosas e tratamento. $1^{a}$ ed. São Paulo:Grupo Editorial Moreira Junior; 2001. p.1-7. 